\title{
INFLUENCE OF POTASSIUM LEVELS ON ROOT GROWTH AND NUTRIENT UPTAKE OF UPLAND RICE CULTIVARS ${ }^{1}$
}

\author{
ANTONIO CARLOS DE ALMEIDA CARMEIS FILHO ${ }^{2 *}$, CARLOS ALEXANDRE COSTA CRUSCIOL ${ }^{2}$, ADRIANO \\ STEPHAN NASCENTE ${ }^{3}$, MUNIR MAUAD ${ }^{4}$, RODRIGO ARROYO GARCIA ${ }^{5}$
}

\begin{abstract}
Potassium $(\mathrm{K})$ is an essential nutrient for upland rice growth, but little information on the effects of $\mathrm{K}$ on root growth and nutrient uptake capacity of upland rice is found. Therefore, an experiment was conducted under greenhouse conditions to evaluate the influence of soil $\mathrm{K}$ levels on root growth and nutrient uptake of four upland rice cultivars. A completely randomized experimental design, in a $4 \times 4$ factorial scheme (4 levels of K: 20, 40, 80, and $160 \mathrm{mg} \mathrm{dm}^{-3}$; 4 cultivars: Caiapó, BRS-Primavera, IAC-202, and Maravilha) was used, with four replications. Based on regression equations, the highest values of root length density would be found with $136 \mathrm{mg} \mathrm{dm}^{-3}$ of $\mathrm{K}$. The root diameter and dry matter, shoot dry matter and shoot $\mathrm{K}$ concentration increased linearly with the increasing $\mathrm{K}$ rates. The shoot $\mathrm{K}$ concentration of the upland rice cultivars did not differ. The increased level of $\mathrm{K}$ in the soil reduced the shoot $\mathrm{Ca}$ concentration of intermediate and modern cultivars, and the shoot $\mathrm{Mg}$ concentration of all cultivars. The potassium fertilization increased the plant growth, but the magnitude of this effect varied according to the cultivar.
\end{abstract}

Key words: Oryza sativa L.. Root length. Plant nutrition.

\section{INFLUÊNCIA DE NÍVEIS DE POTÁSSIO NO CRESCIMENTO RADICULAR E NA ABSORÇÃO DE NUTRIENTES EM CULTIVARES DE ARROZ DE TERRAS ALTAS}

RESUMO - O potássio (K) é um nutriente essencial para o crescimento do arroz, no entanto existem poucas informações sobre os efeitos do $\mathrm{K}$ no crescimento radicular e na capacidade de absorção de nutrientes por diferentes cultivares de arroz de terras altas. Um experimento foi conduzido em casa de vegetação para avaliar a influência de diferentes níveis de $\mathrm{K}$ no solo no crescimento radicular e absorção de nutrientes de quatro cultivares de arroz de terras altas. O delineamento experimental foi inteiramente casualizado, em esquema fatorial 4x4, (4 níveis de K: 20, 40, 80 e $160 \mathrm{mg} \mathrm{dm}^{-3} ; 4$ cultivares: Caiapó, BRS-Primavera, IAC-202 e Maravilha), com quatro repetições. Com base nas equações de regressão, o maior valor para comprimento radicular seria obtido com aplicação de $136 \mathrm{mg} \mathrm{dm}^{-3}$ de $\mathrm{K}$. O diâmetro e a matéria seca radicular, a concentração de K e a biomassa da parte aérea aumentaram linearmente com o aumento das doses de K, porém a concentração de $\mathrm{K}$ na parte aérea não diferiu entre as cultivares de arroz. $\mathrm{O}$ aumento do nível de $\mathrm{K}$ no solo reduziu a concentração $\mathrm{Ca}$ na parte aérea das cultivares dos grupos intermediário e moderno, mas a concentração de $\mathrm{Mg}$ reduziu em todas as cultivares. A adubação potássica aumentou o desenvolvimento das plantas, variando de acordo com o genótipo.

Palavras chave: Oryza sativa L.. Comprimento Radicular. Nutrição mineral.

\footnotetext{
*Corresponding author

${ }^{1}$ Received for publication in 01/28/2015; accepted in 07/11/2016

${ }^{2}$ Department of Crop Science, College of Agricultural Sciences, Universidade Estadual Paulista "Júlio de Mesquita Filho", Botucatu, SP, Brazil; tonycarmeis@hotmail.com,crusciol@fca.unesp.br.

${ }^{3}$ Rice and Beans Research Center, Empresa Brasileira de Pesquisa Agropecuária, Santo Antônio de Goiás, GO, Brazil; adriano.nascente@embrapa.br.

${ }^{4}$ College of Agricultural Sciences, Universidade Federal da Grande Dourados, Dourados, MS, Brazil; munirmauad@ufgd.edu.br.

${ }^{5}$ Western Region Agriculture, Empresa Brasileira de Pesquisa Agropecuária, Dourados, MS, Brazil; rodrigo.garcia@embrapa.br.
} 


\section{INTRODUCTION}

Rice (Oryza sativa L.) is grown in Brazil using two different cropping systems, upland and lowland (SANTOS; STONE; VIEIRA, 2006). The plant yield capacity is reduced under upland conditions, mainly due to water stress, however, inadequate application of nutrients has also been reported as an important limiting factor of plant growth (CLOVER; MALLARINO, 2013; LOPES et al., 2013).

Potassium $(\mathrm{K})$ is extracted from the soil in large amounts by upland rice plants (SLATON et al., 2009; FAGERIA; MOREIRA; COELHO, 2011b). The accumulation of $\mathrm{K}$ in rice shoots can reach 245 $\mathrm{kg} \mathrm{ha}{ }^{-1}$, exhibiting greater rates than nitrogen, according to the cultivar and environmental condition (CRUSCIOL et al., 2016). The main role of $\mathrm{K}$ in plants is the osmoregulation of cells and tissues (FAGERIA; BALIGAR; JONES, 2011a), therefore, the increase in rice grain yield due to $K$ fertilization is not as significant as the increases due to nitrogen and phosphorus fertilization, even considering the variations among cultivars (FARINELLI et al., 2004).

The characteristics of the upland rice root system may be an important factor to increase the $\mathrm{K}$ fertilization effect on grain yield, but little is known about their mechanisms. Root systems can develop significantly to uptake water and nutrients, even under low K availability (FAGERIA; BALIGAR; LI, 2008; GUIMARÃES et al., 2011). Although the pattern of root growth is controlled genetically, the soil chemical properties can modify the root architecture (SAINJU et al., 2005). Zobel (2003) confirmed that the root length density is usually affected by both factors (genotype and soil conditions), but the root diameter is more influenced by soil conditions.

Fageria and Moreira (2011) reported that the upland rice root system comprises $22 \%$ of the total plant dry matter, and that $70 \%$ of the root system is concentrated in the first $20 \mathrm{~cm}$, and $90 \%$ in the first $40 \mathrm{~cm}$ of the soil, however, these characteristics can be modified according to soil chemical condition. A more vigorous root system allows better plant adaptation to water stress, maintaining the plant's ability to uptake water and nutrients, resulting in greater yield, particularly in non-irrigated crop systems.

Some authors have studied the effects of $\mathrm{K}$ fertilization on plant root growth (COSTA et al., 2009), however, little information is available on upland rice. In addition, previous studies were conducted, in general, evaluating the effect of $\mathrm{K}$ fertilization on yield components, grain production and quality parameters of upland rice cultivars (FARINELLI et al., 2004; ZARATIN et al., 2004), and the effect of $\mathrm{K}$ levels on root growth are little investigated. This information is important to adjust the recommendations of $\mathrm{K}$ rates for upland rice, especially in areas without irrigation and with frequent dry spells during rainfall season. Therefore, the objective of this study was to evaluate the influence of soil $\mathrm{K}$ levels on root growth and nutrient uptake of upland rice cultivars.

\section{MATERIAL AND METHODS}

The experiment was conducted under greenhouse conditions, in Botucatu SP, Brazil. Samples from the layer 0-20 $\mathrm{cm}$ of a Hapludox soil were collected, which had $690 \mathrm{~g} \mathrm{~kg}^{-1}$ of sand, $160 \mathrm{~g} \mathrm{~kg}^{-1}$ of clay and $150 \mathrm{~g} \mathrm{~kg}^{-1}$ of silt per sample. Soil chemical attributes were determined $(0-20 \mathrm{~cm})$ according to Raij et al. (2001), before the experiment was implemented (Table 1). The field capacity of the unstructured soil portion (sieved) in free drainage was determined at $-0.03 \mathrm{MPa}$ in a Richards extractor device, which resulted in $180 \mathrm{~g} \mathrm{~kg}^{-1}$.

Table 1. Soil chemical properties prior to experiment initiation.

\begin{tabular}{|c|c|c|c|c|c|c|c|c|}
\hline Layer & $\begin{array}{c}\mathrm{pH} \\
\left(\mathrm{CaCl}_{2}\right) \\
\end{array}$ & $\mathrm{P}$ (resin) & $\mathrm{H}+\mathrm{Al}$ & $\mathrm{Ca}^{2+}$ & $\mathrm{Mg}^{2+}$ & $\mathrm{K}^{+}$ & CEC & $\mathrm{BS}^{1}$ \\
\hline $\mathrm{cm}$ & & $\mathrm{mg} \mathrm{dm}^{-3}$ & & - & $\mathrm{nol}_{\mathrm{c}} \mathrm{dr}$ & ----- & & $\%$ \\
\hline $0-20$ & 3.8 & 2.0 & 52 & 5.0 & 1.0 & 0.2 & 58.2 & 10.6 \\
\hline
\end{tabular}

${ }^{1} \mathrm{BS}$ : base saturation.

The experiment was conducted in a completely randomized experimental design, in a $4 \times 4$ factorial scheme, with four replications. The treatments consisted of four K levels $(20,40,80$ and $160 \mathrm{mg} \mathrm{dm}^{-3}$ ) and four cultivars of upland rice (Caiapó - traditional type, IAC-202 and BRS-Primavera - intermediate type and Maravilha modern type). Each experimental unit (plot) consisted of a $12 \mathrm{dm}^{-3}$ polyethylene pot.

The characteristics of the four cultivars, which are used for rice production in upland systems, are described below according to the methods of Santos, Stone, and Vieira (2006).

Caiapó (released in 1992) is from the traditional type group. It produces tall plants with long and decumbent leaves and a low tillering capacity, and has the disadvantage of plant lodging in fertile soils or when fertilized with high rates of nitrogen.

Maravilha (released in 1996) is from the 
modern group. It produces short plants, short and erect leaves, strong stems, has high tillering and respond to fertilization without lodging, improving soil fertility and nitrogen fertilization.

$I A C-202$ (released in 1998) and
BRS-Primavera (released in 1997) are from the intermediate group. They produce plants that have intermediate characteristics between the traditional and modern groups.

Lime ( $\mathrm{CaO} 24 \%$; $\mathrm{MgO} 18 \%)$ was applied to the sieved soil to increase its base saturation up to $60 \%$. Subsequently, $10 \mathrm{~kg}$ of soil samples were packed in plastic bags with a water content of approximately $180 \mathrm{~g} \mathrm{~kg}^{-1}$ (field capacity) and incubated for 30 days. After this period, $120 \mathrm{mg} \mathrm{dm}^{-3}$ of nitrogen fertilizer (urea 44\% N) was applied (60 mg dm $\mathrm{mg}^{-3}$ at sowing and $60 \mathrm{mg} \mathrm{dm}^{-3}$ top-dressed at early tillering), as well as $100 \mathrm{mg} \mathrm{dm}^{-3}$ of $\mathrm{P}$ (triple superphosphate), the $\mathrm{K}$ levels (potassium chloride), $2 \mathrm{mg} \mathrm{dm}$ of boron (boric acid) and $5 \mathrm{mg}^{-3}$ of $\mathrm{Zn}$ (oxide zinc), in each pot

Ten seeds were sown per pot, and the plantlets were thinned to 4 specimens per pot. Soil moisture was monitored daily during the experiment by weighing the pots and applying water when transpiration reached $85 \%$ of the soil water field capacity. The upland rice plants were collected when they reached the full flowering stage (GUIMARÃES et al., 2011). After the crop harvest, soil samples were collected to determine the exchangeable $\mathrm{K}$ content in the soil, following the methods proposed by Raij et al. (2001). The plants were sectioned, separating shoots and roots. The soil in the roots was cleaned by washing them in running water over a $0.5 \mathrm{~mm}$-mesh sieve. The root length and mean diameter were measured through image scanning using an HP Scanjet 4c/T and the Reg WinRhizo $3.8 \mathrm{~b}$ software (Regent Instruments Inc.), following the method proposed by Tennant (1975). The roots were dried at $65^{\circ} \mathrm{C}$ for $72 \mathrm{~h}$ and weighed to determine their biomass (g plant $\left.{ }^{-1}\right)$.

The shoots were washed in running water, dried in a forced air circulation oven at $65^{\circ} \mathrm{C}$, and then weighed to determine their dry matter. Based on the sum of the dry matter of roots and shoots, the total dry matter, as well as the relationship between these parameters were calculated. Sub-samples of shoots were collected to determine the concentrations of $\mathrm{N}, \mathrm{P}, \mathrm{K}, \mathrm{Ca}, \mathrm{Mg}, \mathrm{S}$ and $\mathrm{Zn}$ following the methods of Malavolta, Vitti and Oliveira (1997).

The uptake of N, P, K, Ca, Mg, S and $\mathrm{Zn}$ was determined using the data on the shoot dry matter, nutrient concentrations and nutrient content in the shoots. The nutrient uptake in relation to the root length was determined by dividing the nutrient levels in the plant by root length (ROSOLEM et al., 1993; SANTOS; STONE; VIEIRA, 2006). Nutrient use efficiency was calculated by dividing the shoot dry matter by the nutrient shoot content
(CRUSCIOL et al., 2013).

The data on the roots (length density, diameter, and dry matter) as well as the shoot and total dry matter, nutrient concentration, nutrient content, nutrient uptake per root length and nutrient use efficiency, were analyzed through two-way ANOVA with the Statistical Software Package SAS (SAS INSTITUTE, 1999). The different upland rice cultivars and $\mathrm{K}$ levels were considered fixed effects (independent factors). Data was analyzed using the LSD test $(\mathrm{P} \leq 0.05)$. Regression analysis was employed for the $\mathrm{K}$ levels.

\section{RESULTS AND DISCUSSION}

The exchangeable $\mathrm{K}$ content in the soil increased after the harvest, depending on the amount of $\mathrm{K}$ applied, exhibiting a quadratic effect (Figure 1). Based on the regression equation, the excess of $\mathrm{K}$ in the soil treated with $160 \mathrm{mg} \mathrm{dm}^{-3}$ of $\mathrm{K}$ probably increased the ion acquisition by root cells, inducing a high accumulation of $\mathrm{K}$ by the plants. Due to specific $\mathrm{K}$ transporter mechanisms in the root membrane cells, $\mathrm{K}$ uptake in some species, such as rice, is very high (CRUSCIOL et al., 2016), and the availability of this nutrient in the soil plays a fundamental role in the $\mathrm{K}$ accumulation in these plants (KAMINSKI et al., 2007). The leaching effect must not be considered, because the irrigation was monitored to avoid water excess.

The modern-type cultivar Maravilha has high yield potential and photosynthetic efficiency (SANTOS; STONE; VIEIRA, 2006), but this genotype showed a lower root length density compared to cultivars from the intermediate group (IAC-202 and BRS-Primavera) (Table 2). Maravilha presented the shortest root length, probably because this cultivar was intended for cultivation under irrigation or in areas with adequate rainfall conditions, thus, requiring smaller root system for water and nutrient uptake (SANTOS; STONE; VIEIRA, 2006; GUIMARÃES et al., 2011). According to Hsiao et al. (2009) and Fageria and Moreira (2011), the root length density is a characteristic that is genetically controlled, leading to differences among cultivars, as observed in the present experiment. Potassium deficiency has variable influence on physiological mechanisms of different rice genotypes (YANG et al. 2005). In addition to the genetic factors, the availability of $\mathrm{K}$ in the soil can influence the root growth. Based on the regression equation, the highest root length density would be reached with $136 \mathrm{mg} \mathrm{dm}^{-3}$ of $\mathrm{K}$ (Figure 2a), confirming the effect of $\mathrm{K}$ availability in root morphology. Similar results were observed by Hallmark and Barber (1981) for a soybean species. Therefore, potassium deficiency can affect root morphology and reduce root growth. 


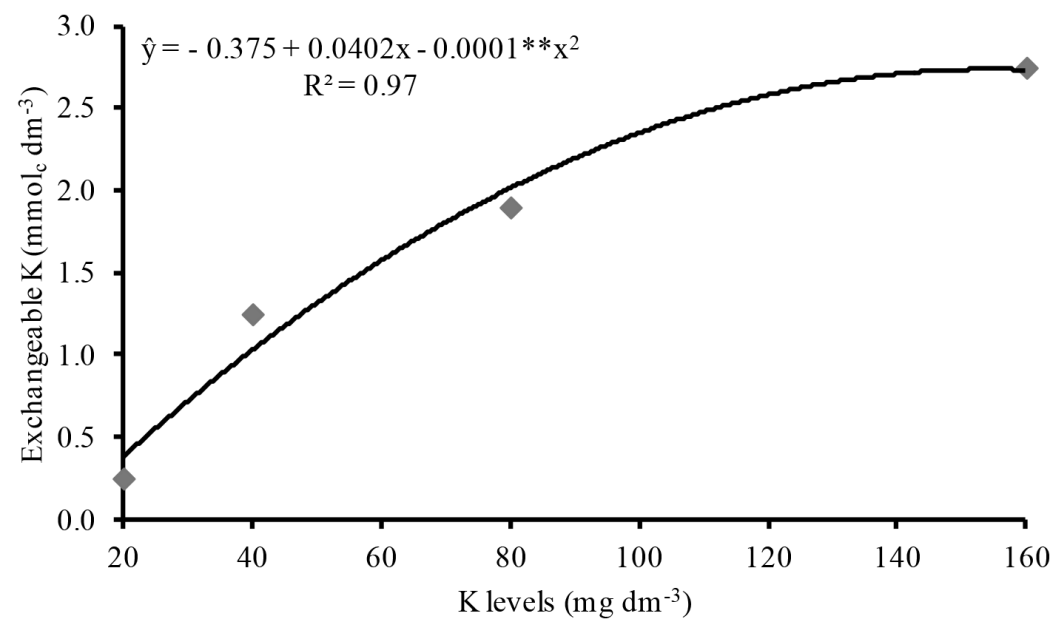

Figure 1. Exchangeable $\mathrm{K}$ contents in the soil as affected by increasing $\mathrm{K}$ levels. $* *$ significantly different at $\mathrm{p} \leq 0.01$.

Table 2. Length, diameter, and dry matter of the root system, shoot dry matter, total dry matter, and root/shoot dry matter ratio of upland rice as affected by cultivar and increasing $\mathrm{K}$ levels.

\begin{tabular}{|c|c|c|c|c|c|c|}
\hline Treatments & $\begin{array}{c}\text { Root } \\
\text { lenght }\end{array}$ & $\begin{array}{c}\text { Root } \\
\text { diameter }\end{array}$ & $\begin{array}{c}\text { Root dry } \\
\text { matter }\end{array}$ & $\begin{array}{c}\text { Shoot dry } \\
\text { matter }\end{array}$ & $\begin{array}{c}\text { Total dry } \\
\text { matter }\end{array}$ & $\begin{array}{l}\text { Root/Shoot } \\
\text { ratio }\end{array}$ \\
\hline Cultivars & $\mathrm{m} \mathrm{plant}^{-1}$ & $\mathrm{~mm}$ & g plant $^{-1}$ & g plant $^{-1}$ & g plant $^{-1}$ & \\
\hline Maravilha & $64.1 b^{1}$ & $0.14 \mathrm{a}$ & $7.4 \mathrm{a}$ & $5.0 \mathrm{a}$ & $12.4 \mathrm{a}$ & $1.4 \mathrm{a}$ \\
\hline Caiapó & $72.3 \mathrm{ab}$ & $0.13 \mathrm{a}$ & $6.9 \mathrm{a}$ & $5.2 \mathrm{a}$ & $12.1 \mathrm{a}$ & $1.3 \mathrm{a}$ \\
\hline IAC 202 & $81.7 \mathrm{a}$ & $0.18 \mathrm{a}$ & $7.5 \mathrm{a}$ & $4.9 \mathrm{a}$ & $12.4 \mathrm{a}$ & $1.5 \mathrm{a}$ \\
\hline BRS Primavera & $83.8 \mathrm{a}$ & $0.16 \mathrm{a}$ & $8.3 \mathrm{a}$ & $5.4 \mathrm{a}$ & $13.7 \mathrm{a}$ & $1.5 \mathrm{a}$ \\
\hline ANOVA (F probability) & & & & & & \\
\hline Cultivar (C) & 0.0071 & 0.2937 & 0.5000 & 0.3157 & 0.4595 & 0.4484 \\
\hline K level (L) & $<0.0001$ & 0.0033 & $<0.0001$ & $<0.0001$ & $<0.0001$ & 0.0079 \\
\hline $\mathrm{C} \times \mathrm{L}$ & 0.1724 & 0.8050 & 0.9811 & 0.3246 & 0.9529 & 0.8819 \\
\hline CV (\%) & 21.60 & 31.58 & 35.72 & 14.10 & 24.11 & 28.69 \\
\hline
\end{tabular}

${ }^{1}$ Values followed by the same letter vertically are not significantly different at $\mathrm{p}<0.05$ according to a LSD test.

According to Yang et al. (2005), rice roots cause changes in the $\mathrm{K}$ fractionation and mobility in the rhizosphere, which may influence the uptake of $\mathrm{K}$, root growth and crop yields. The potassium fertilization generated significant changes in root diameter (Table 2), which increased linearly with the increase of $\mathrm{K}$ rates (Figure $2 \mathrm{~b}$ ). The plants under low level of $\mathrm{K}$, exhibited more favorable architecture for nutrient uptake, with thin roots. The main mode of nutrient transport from the soil solution to the plant is diffusion (FAGERIA; BALIGAR; JONES, 2011a), thus, the small root diameter found with the lowest $\mathrm{K}$ rates may benefit the plant adaptation, enabling the roots more efficiently to reach the nutrients in the soil (FAGERIA; BALIGAR; JONES, 2011a). For example, under low levels of $\mathrm{K}$ in the soil, the plant may have low root dry matter production as a result of reduced growth, while a proportional increase in the number of thin roots may increase the plant nutrient uptake ability (HALLMARK; BARBER, 1981). Similar results have been reported by Crusciol et al. (2005) for P fertilization. Roots with a small diameter are extremely important for plant development, since 90 $-95 \%$ of the root length consists of roots with diameter less than $0.6 \mathrm{~mm}$ (ZOBEL, 2003; FAGERIA; BALIGAR; JONES, 2011a).

Potassium deficiency can significantly affect the root morphology, linearly increasing the root dry matter, and also the shoot and total dry matter production to a quadratic behavior, with the addition of $\mathrm{K}$ rates in the soil (Figure 2c). According to the regression model, the maximum values of shoot and total dry matter would be achieved with 146 and $151 \mathrm{mg} \mathrm{dm}^{-3}$ of $\mathrm{K}$, respectively (Figure $3 \mathrm{a}$ and $3 \mathrm{~b}$ ). The increase in shoot dry matter observed with the highest rate of $\mathrm{K}$ was 2.95 -fold higher than that with the lowest rate of $\mathrm{K}$, while in the root system, the increase was only 1.89 -fold higher than that with the lowest rate of $\mathrm{K}$. Thus, the distribution of photoassimilates in the shoots and roots was altered, and the relationship increased as a function of the $\mathrm{K}$ availability in the soil (Figure 2F). No interaction was observed between the cultivars and $\mathrm{K}$ rates, but the $\mathrm{K}$ added to the soil increased the root growth (Table 2). 

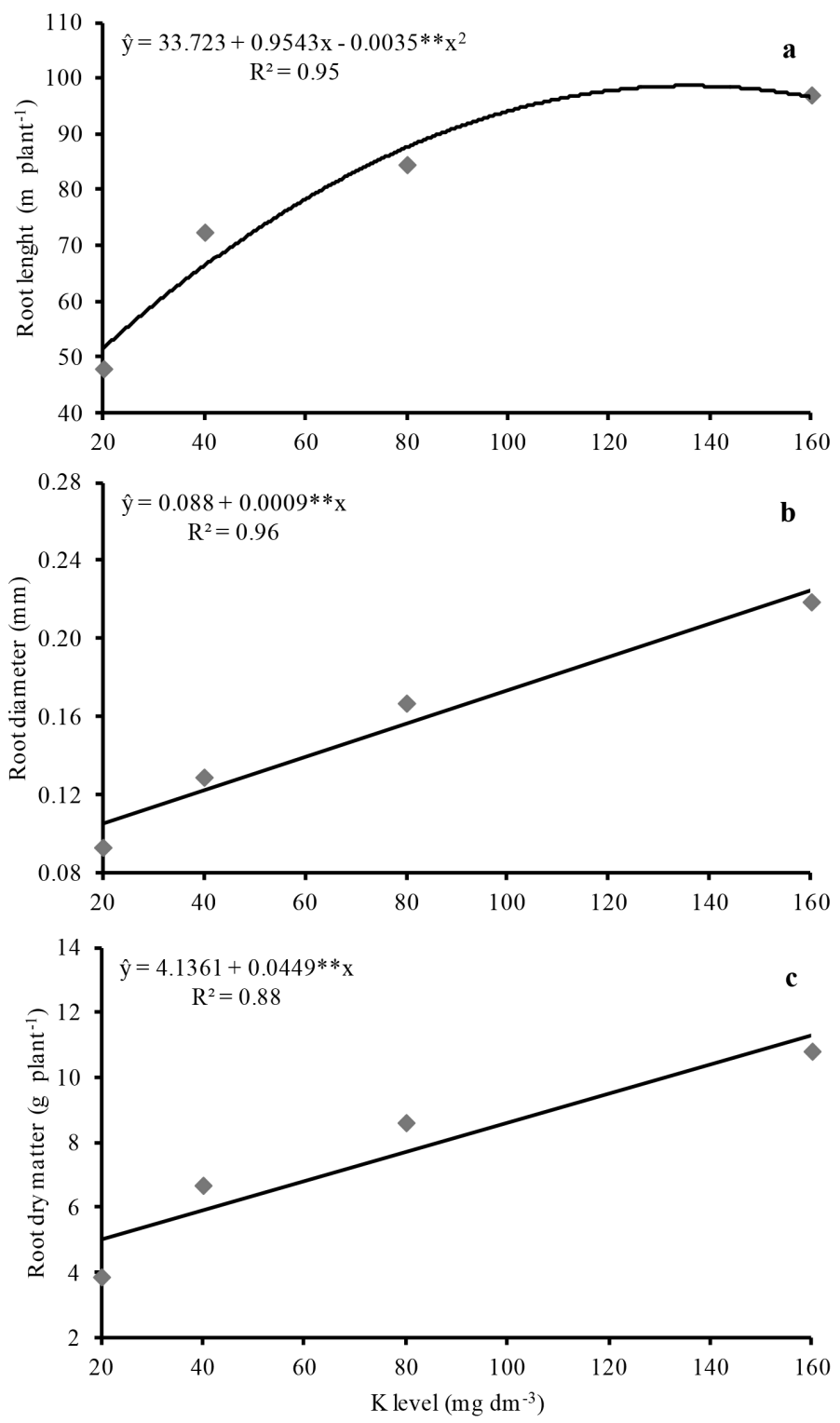

Figure 2. Length (a), diameter (b), and root dry matter (c) of upland rice as affected by increasing K levels. **significantly different at $\mathrm{p} \leq 0.01$.

Despite the differences in root length density found among the upland rice cultivars (Table 2), no differences were found for $\mathrm{N}, \mathrm{P}$, and $\mathrm{K}$ concentration in the shoots (Table 3). Regarding N, this result may be due to the high mobility of nitrate in the soil, which allows contact between ions and roots (FAGERIA; BALIGAR; LI, 2008). Therefore, even in the treatments where shorter root lengths were found, N uptake was not reduced. Regarding $\mathrm{P}$, this nutrient exhibits low mobility in the soil, however, rice plants require low $\mathrm{P}$ levels, showing a low uptake rate (SANTOS; STONE; VIEIRA, 2006; CRUSCIOL et al., 2016).
Potassium concentration in the shoots was similar among the cultivars (Table 3), however, differences in root length were found as a function of $\mathrm{K}$ fertilization and type of plant. Although genetic factors did not influence $\mathrm{K}$ concentration in the shoot, the higher availability of $\mathrm{K}$ in the soil improved the K uptake rate by plants (Figure 2a). Similar results were reported by Slaton et al. (2009), and Guimarães et al. (2011) in rice and Clover and Mallarino (2013) in corn and soybean. Therefore, the contact between ions and roots increases with the increase of $\mathrm{K}$ availability in the soil, contributing to greater $\mathrm{K}$ uptake by the roots. 

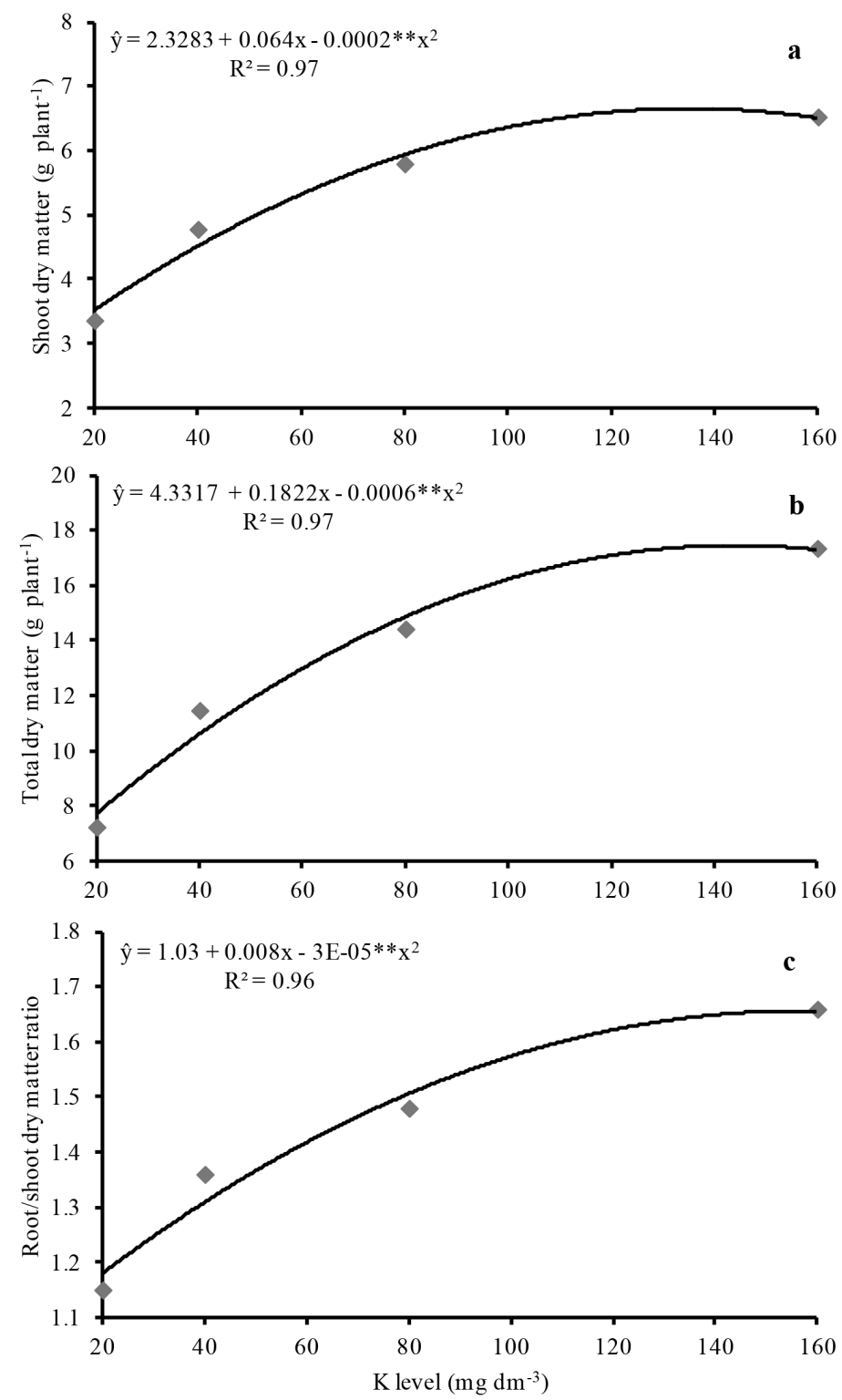

Figure 3. Shoot dry matter (a), total dry matter (b), and root/shoot dry matter ratio (c) for upland rice as affected by increasing $\mathrm{K}$ levels. ${ }^{* *}$ significantly different at $\mathrm{p} \leq 0.01$.

Table 3. Nutrient concentration in the shoot of upland rice as affected by cultivar and increasing $\mathrm{K}$ levels.

\begin{tabular}{|c|c|c|c|c|c|c|c|}
\hline Treatments & $\mathrm{N}$ & $\mathrm{P}$ & $\mathrm{K}$ & $\mathrm{Ca}$ & $\mathrm{Mg}$ & $\mathrm{S}$ & $\mathrm{Zn}$ \\
\hline Cultivars & \multicolumn{6}{|c|}{$\mathrm{g} \mathrm{kg}^{-1}$} & $\overline{m g ~ \mathrm{~kg}^{-1}}$ \\
\hline Maravilha & $45 a^{1}$ & $3.1 \mathrm{a}$ & $20 \mathrm{a}$ & $11.3 \mathrm{a}$ & $4.7 \mathrm{~b}$ & $3.2 \mathrm{a}$ & $27 \mathrm{~b}$ \\
\hline Caiapó & $46 \mathrm{a}$ & $3.4 \mathrm{a}$ & $18 \mathrm{a}$ & $9.3 \mathrm{~b}$ & $4.5 \mathrm{~b}$ & $2.8 \mathrm{~b}$ & $27 \mathrm{~b}$ \\
\hline IAC 202 & $50 \mathrm{a}$ & $3.3 \mathrm{a}$ & $19 \mathrm{a}$ & $9.7 \mathrm{~b}$ & $5.1 \mathrm{a}$ & $3.2 \mathrm{a}$ & $21 \mathrm{~b}$ \\
\hline BRS Primavera & $47 \mathrm{a}$ & $3.4 \mathrm{a}$ & $18 \mathrm{a}$ & $11.2 \mathrm{a}$ & $4.5 \mathrm{~b}$ & $3.1 \mathrm{a}$ & $34 \mathrm{a}$ \\
\hline \multicolumn{8}{|c|}{ ANOVA (F probability) } \\
\hline Cultivar (C) & 0.3938 & 0.0411 & 0.6689 & $<0.0001$ & 0.0039 & 0.0238 & 0.0083 \\
\hline K level (L) & 0.0771 & 0.1377 & $<0.0001$ & 0.0003 & $<0.0001$ & $<0.0001$ & 0.9611 \\
\hline $\mathrm{C} \times \mathrm{L}$ & 0.8568 & 0.1271 & 0.6781 & 0.1351 & 0.1121 & 0.3009 & 0.5663 \\
\hline $\mathrm{CV}(\%)$ & 11.26 & 10.40 & 9.84 & 7.86 & 10.35 & 12.97 & 8.93 \\
\hline
\end{tabular}

${ }^{1}$ Values followed by the same letter vertically are not significantly different at $\mathrm{p}<0.05$ according to a LSD test.

Differences among the cultivars regarding the $\mathrm{Ca}, \mathrm{Mg}, \mathrm{S}$ and $\mathrm{Zn}$ concentrations in the shoot were found (Table 3). The modern and intermediate cultivars (Maravilha and BRS-Primavera) presented more efficient uptake and $\mathrm{Ca}$ transport, and the BRS-Primavera presented greater shoot $\mathrm{Zn}$ concentration. The highest $\mathrm{Mg}$ concentration was found in the cultivar $I A C$-202, probably because of the presence of a more specific carrier of $\mathrm{Mg}$ in the root system, resulting in higher levels of $\mathrm{Mg}$ uptake compared to those by the other cultivars, however, this specific carrier was not measured to confirm this 
hypothesis. According to Tanoi et al. (2011), the genetic characteristics can implicate in biosynthesis of specific proteins, with action on $\mathrm{Mg}$ transport. The cultivar Caiapó (traditional group) had lower values for $\mathrm{Ca}, \mathrm{S}$ and $\mathrm{Zn}$ concentration in the shoot compared to the BRS-Primavera (intermediate group). According to Fageria, Baligar and Li (2008), these results are due to genetic characteristics that control the versatility of specific carriers involved in ion uptake through the plasmatic membrane of the root cells. The specificity and selectivity of these protein carriers are directly related to the use efficiency of mineral fertilizers (FAGERIA; BALIGAR; JONES, 2011a).

The shoot $\mathrm{K}$ concentrations increased linearly with the increasing $\mathrm{K}$ rates (Figure $4 \mathrm{a}$ ). In contrast,
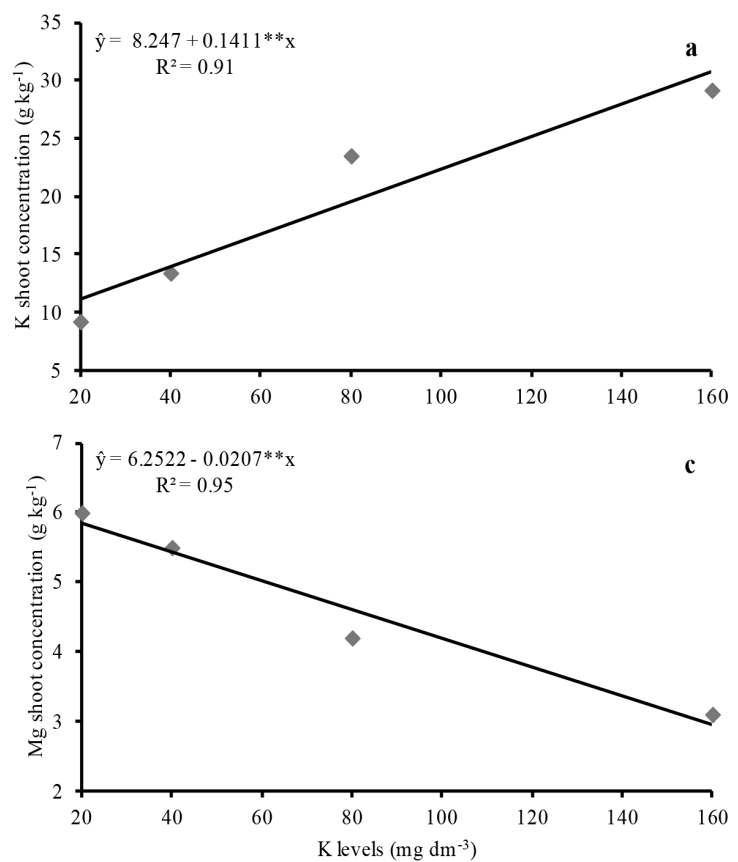

Figure 4. Potassium (a), calcium (b), magnesium (c), and sulfur (d) concentration in the shoot of upland rice as affected by increasing $\mathrm{K}$ levels. ${ }^{* *}$ significantly different at $\mathrm{p} \leq 0.01$.

Cultivars Maravilha and BRS-Primavera cultivars showed greater Ca shoot contents (Table 4), probably because these cultivars had higher shoot $\mathrm{Ca}$ concentration than the other cultivars. Similarly, BRS -Primavera had higher values of $\mathrm{Zn}$ concentration the concentrations of $\mathrm{Ca}, \mathrm{Mg}$ and $\mathrm{S}$ in the shoot decreased with the increasing $\mathrm{K}$ rates (Figures $4 \mathrm{~b}, 4 \mathrm{c}$ and $4 \mathrm{~d})$. This result indicates interaction effects between $\mathrm{K}$ and other cations such as $\mathrm{Ca}$ and $\mathrm{Mg}$ (DALIPARTHYA; BARKER; MODAL, 1994). Rosolem et al. (1993) found in a three-year experiment that an annual $\mathrm{K}$ fertilization of 120 or $180 \mathrm{~kg} \mathrm{ha}{ }^{-1}$ of $\mathrm{K}_{2} \mathrm{O}$ decreases $\mathrm{Ca}$ and $\mathrm{Mg}$ concentrations in soybean plants. A negative effect of $\mathrm{K}$ fertilizer was also observed on $\mathrm{S}$ uptake, probably due to an antagonistic effect between the $\mathrm{Cl}$ from $\mathrm{KCl}$ and $\mathrm{SO}_{4}$ (ORTEGA; MALAVOLTA, 2012). In addition, the results found in the present work regarding nutrient concentrations may be related to differences in nutrient uptake efficiency among cultivars (FAGERIA; MOREIRA, 2011).
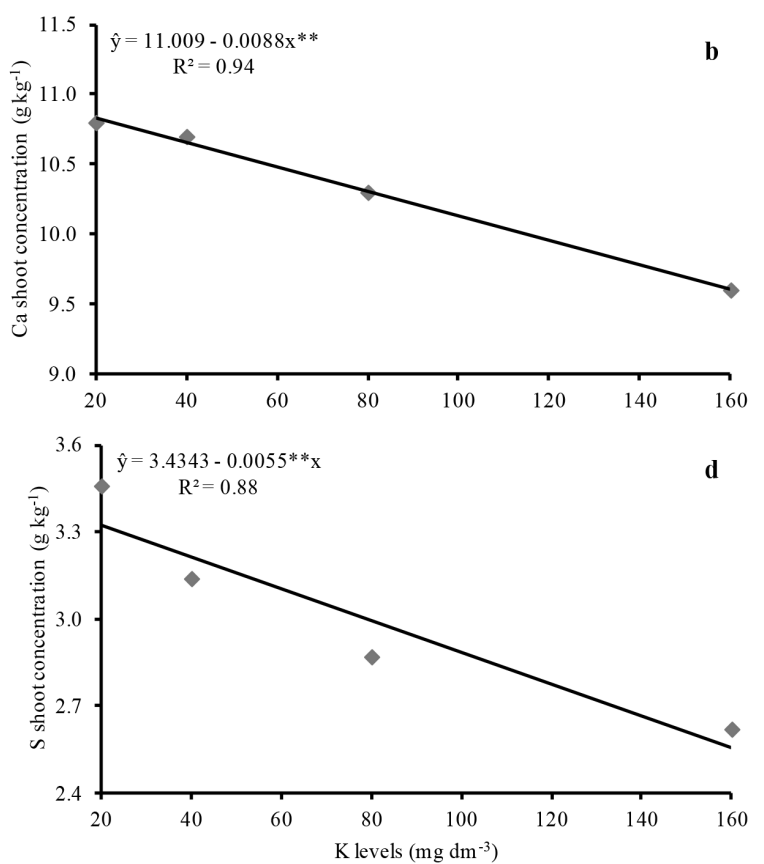

Table 4. Nutrient content in the shoot of upland rice as affected by cultivar and increasing K levels.

\begin{tabular}{|c|c|c|c|c|c|c|c|}
\hline Treatments & $\mathrm{N}$ & $\mathrm{P}$ & $\mathrm{K}$ & $\mathrm{Ca}$ & $\mathrm{Mg}$ & $\mathrm{S}$ & $\mathrm{Zn}$ \\
\hline Cultivars & \multicolumn{6}{|c|}{ g plant $^{-1}$} & $\mathrm{mg} \mathrm{plant}^{-1}$ \\
\hline Maravilha & $0.222 \mathrm{a}^{1}$ & $0.016 \mathrm{a}$ & $0.107 \mathrm{a}$ & $0.056 \mathrm{a}$ & $0.022 \mathrm{a}$ & $0.016 \mathrm{a}$ & $0.135 \mathrm{~b}$ \\
\hline Caiapó & $0.234 \mathrm{a}$ & $0.016 \mathrm{a}$ & $0.103 \mathrm{a}$ & $0.048 \mathrm{~b}$ & $0.023 \mathrm{a}$ & $0.014 \mathrm{a}$ & $0.133 \mathrm{~b}$ \\
\hline IAC 202 & $0.240 \mathrm{a}$ & $0.017 \mathrm{a}$ & $0.102 \mathrm{a}$ & $0.047 \mathrm{~b}$ & $0.024 \mathrm{a}$ & $0.015 \mathrm{a}$ & $0.103 \mathrm{~b}$ \\
\hline BRS Primavera & $0.246 \mathrm{a}$ & $0.018 \mathrm{a}$ & $0.107 \mathrm{a}$ & $0.060 \mathrm{a}$ & $0.023 \mathrm{a}$ & $0.016 \mathrm{a}$ & $0.183 \mathrm{a}$ \\
\hline \multicolumn{8}{|l|}{$\begin{array}{l}\text { ANOVA } \\
\text { (F probability) }\end{array}$} \\
\hline Cultivar (C) & 0.5195 & 0.1073 & 0.9455 & 0.0002 & 0.6885 & 0.2055 & 0.0128 \\
\hline K level (L) & $<0.0001$ & $<0.0001$ & $<0.0001$ & $<0.0001$ & 0.0923 & $<0.0001$ & 0.0026 \\
\hline $\mathrm{C} \times \mathrm{L}$ & 0.1813 & 0.5955 & 0.9462 & 0.1439 & 0.1091 & 0.4811 & 0.6265 \\
\hline $\mathrm{CV}(\%)$ & 12.87 & 15.18 & 17.82 & 17.01 & 18.20 & 19.17 & 22.72 \\
\hline
\end{tabular}

${ }^{1}$ Values followed by the same letter vertically are not significantly different at $\mathrm{p}<0.05$ according to a LSD test.

Rev. Caatinga, Mossoró, v. 30, n. 1, p. 32 - 44, jan. - mar., 2017 
Potassium levels increased the shoot contents of $\mathrm{N}, \mathrm{P}, \mathrm{K}, \mathrm{Ca}, \mathrm{S}$ and $\mathrm{Zn}$ in the upland rice plants (Figures 5a, 5b, 5c, 6a, 6b and 6c). These increases may be due to its stimulation of root and shoot growth. Medeiros, Soares and Guimarães (2005) reported that plants with well-developed root systems have the ability to exploit a greater soil volume, which is fundamental for increasing the contact between roots and nutrients, resulting in an improvement in nutrient uptake.
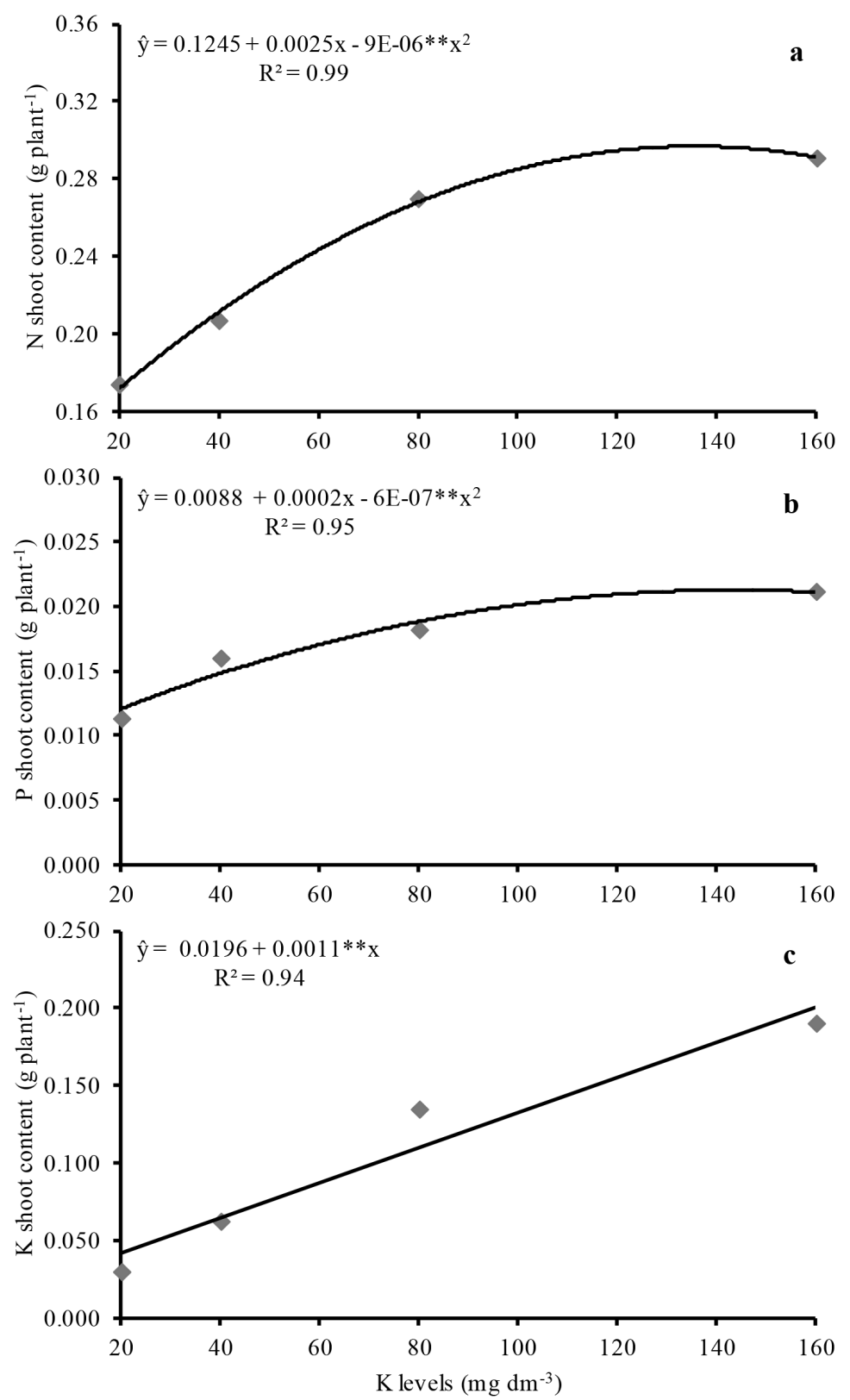

Figure 5. Nitrogen (a), phosphorus (b), and potassium (c) content in the shoot of upland rice as affected by increasing $\mathrm{K}$ levels. ${ }^{*}$ significantly different at $\mathrm{p} \leq 0.01$.

Phosphorus, K, Ca, S and Zn uptake per root length was affected by the genetic factor (Table 5). According to Horn et al. (2006), differences in the kinetic parameters of nutrient uptake is a result of the expression of genetic characteristics, especially on membrane protein transporters in root cells. This result denotes the importance of breeding programs for developing rice cultivars with high capacity of nutrient uptake.
The application of $\mathrm{K}$ promoted greater availability of $\mathrm{K}$ in the soil, increasing the $\mathrm{K}$ diffusion rate in the soil, and consequently, the contact between $\mathrm{K}$ and the rice roots (Figure $7 \mathrm{a}$ ). Similar results were found by Oliveira, Rosolem and Trigueiro (2004) in cotton (Gossypium hirsutum). Conversely, the $\mathrm{Mg}$ and $\mathrm{S}$ uptake per unit of root length was reduced with the increasing $\mathrm{K}$ rates (Figures $7 \mathrm{~b}$ and $7 \mathrm{c}$ ). 

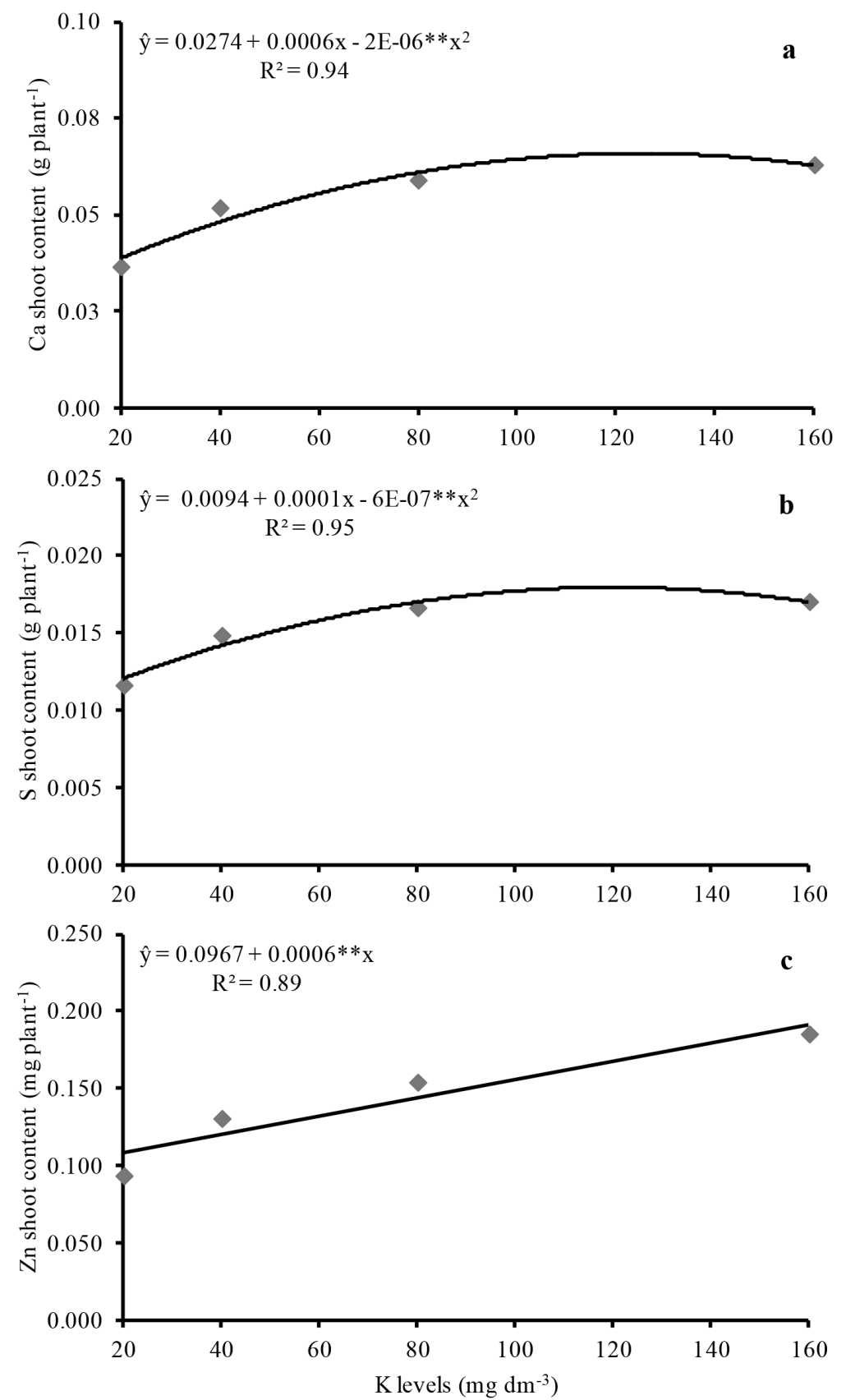

Figure 6. Calcium (a), sulfur (b) and zinc (c) content in the shoot of upland rice as affected by increasing K levels. $* *$ significantly different at $\mathrm{p} \leq 0.01$.

Table 5. Nutrients uptake per unit root length of upland rice as affected by cultivar and increasing K levels.

\begin{tabular}{|c|c|c|c|c|c|c|c|}
\hline Treatments & $\mathrm{N}$ & $\mathrm{P}$ & $\mathrm{K}$ & $\mathrm{Ca}$ & $\mathrm{Mg}$ & $\mathrm{S}$ & $\mathrm{Zn}$ \\
\hline Cultivars & \multicolumn{6}{|c|}{$\mathrm{g} \mathrm{m}^{-1}$} & $\mathrm{mg} \mathrm{m}^{-1}$ \\
\hline Maravilha & $0.004 \mathrm{a}^{1}$ & $0.0003 \mathrm{a}$ & $0.0016 \mathrm{a}$ & $0.0009 \mathrm{a}$ & $0.0004 \mathrm{a}$ & $0.0003 \mathrm{a}$ & $0.002 \mathrm{a}$ \\
\hline Caiapó & $0.003 \mathrm{a}$ & $0.0003 \mathrm{a}$ & $0.0015 \mathrm{ab}$ & $0.0008 \mathrm{~b}$ & $0.0004 \mathrm{a}$ & $0.0002 \mathrm{~b}$ & $0.002 \mathrm{a}$ \\
\hline IAC 202 & $0.003 \mathrm{a}$ & $0.0002 \mathrm{~b}$ & $0.0012 \mathrm{~b}$ & $0.0006 \mathrm{c}$ & $0.0003 \mathrm{a}$ & $0.0002 \mathrm{~b}$ & $0.001 \mathrm{~b}$ \\
\hline BRS Primavera & $0.003 \mathrm{a}$ & $0.0003 \mathrm{a}$ & $0.0013 \mathrm{ab}$ & $0.0008 \mathrm{~b}$ & $0.0003 \mathrm{a}$ & $0.0002 \mathrm{~b}$ & $0.002 \mathrm{a}$ \\
\hline $\begin{array}{l}\text { ANOVA } \\
\text { probability) }\end{array}$ & & & & & & & \\
\hline Cultivar (C) & 0.4756 & 0.5845 & 0.1428 & $<0.0001$ & 0.2521 & 0.0208 & 0.0034 \\
\hline K level (L) & 0.1281 & 0.6159 & $<0.0001$ & 0.1558 & $<0.0001$ & 0.0081 & 0.9838 \\
\hline $\mathrm{C} \times \mathrm{L}$ & 0.2761 & 0.0899 & 0.2347 & 0.0911 & 0.0772 & 0.0644 & 0.1717 \\
\hline $\mathrm{CV}(\%)$ & 22.98 & 18.75 & 17.92 & 20.64 & 23.78 & 21.26 & 24.67 \\
\hline
\end{tabular}

${ }^{1}$ Values followed by the same letter vertically are not significantly different at $\mathrm{p}<0.05$ according to a LSD test. 
The competition between $\mathrm{Mg}^{2+}$ and $\mathrm{K}^{+}$ions for the same binding sites on the carrier during the ion acquisition process is most likely reflected in negative effects on $\mathrm{Mg}$ uptake (MORTVEDT; KHASAWNEH, 1986). A marked imbalance of these two macronutrients can result in nutritional deficiencies and may severely impact the grain yield. The decrease in the $\mathrm{S}$ uptake may be related to the competition between $\mathrm{Cl}^{-}$and $\mathrm{SO}_{4}{ }^{-2}$, however, the $\mathrm{K}$ levels effect on root length density, enhancing plant exploration, may have leaded the rice plants to a lower requirement of $\mathrm{S}$ per unit of root length. Although, this result comes from a greenhouse experiment, where plants were grown in pots with a restrict soil volume, in a field condition the results could be more expressive, since root system can explore a greater volume of soil.
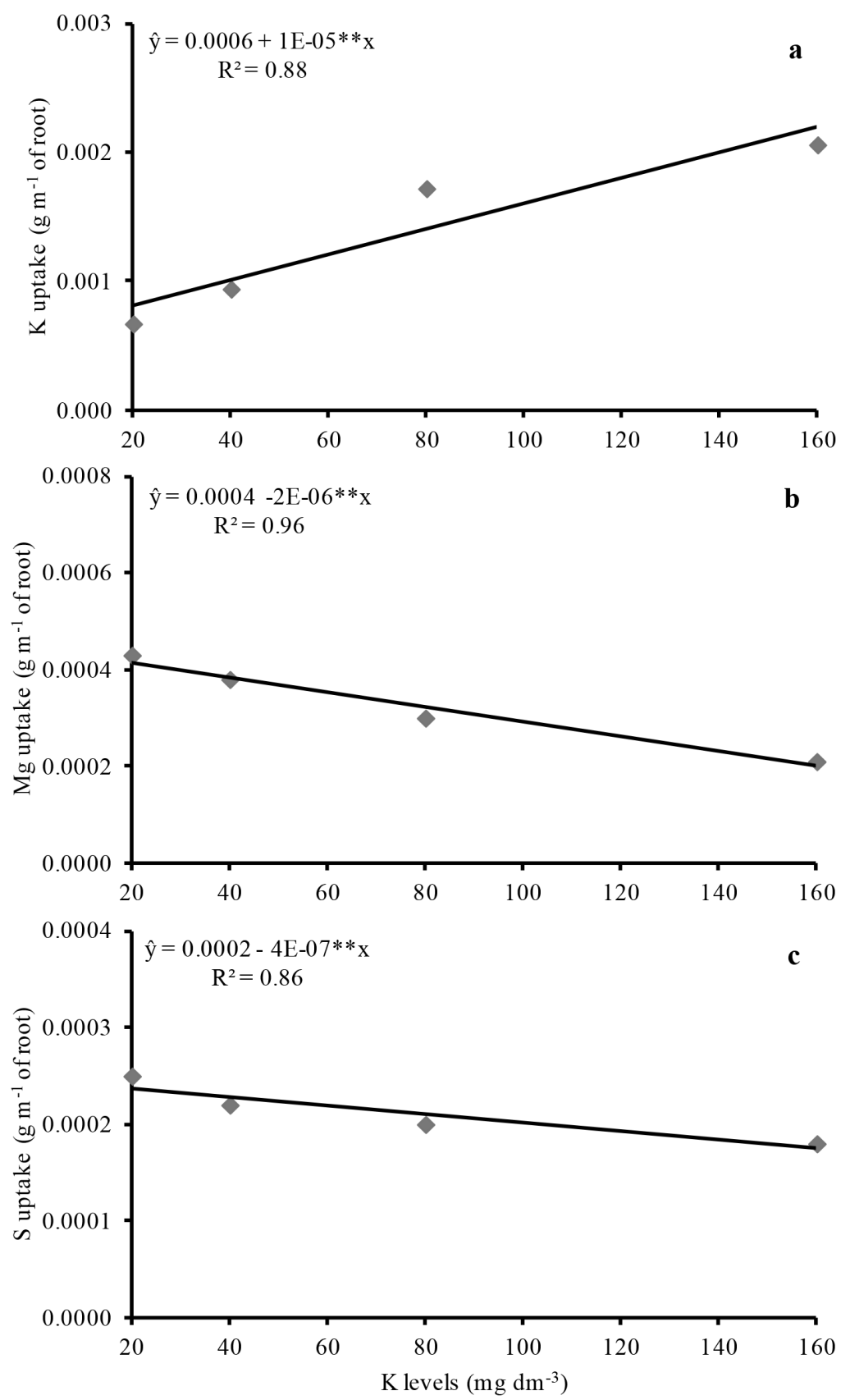

Figure 7. Potassium (a), magnesium (b) and sulfur (c) uptake per unit root length of upland rice as affected by increasing K levels. **significantly different at $\mathrm{p} \leq 0.01$.

The cultivar Caiapó is from the traditional group, however, it had nutrient use efficiency similar to the modern cultivars (Table 6). Only the P use efficiency of Caiapó was lower than that of the modern cultivar (Maravilha). According to Santos,
Stone, and Vieira (2006), Caiapó is highly efficient in nutrient uptake and requires lower amounts of photosynthetic compounds for the formation of vegetative structures. 
A. C. A. CARMEIS FILHO et al.

Table 6. Nutrient use efficiency of upland rice as affected by cultivar and increasing K levels.

\begin{tabular}{lcrrrrrr}
\hline Treatments & $\mathrm{N}$ & $\mathrm{P}$ & $\mathrm{K}$ & $\mathrm{Ca}$ & $\mathrm{Mg}$ & $\mathrm{S}$ & $\mathrm{Zn}$ \\
\hline Cultivars & & \multicolumn{7}{c}{$\mathrm{g} \mathrm{SDM} \mathrm{g} \mathrm{SNC}$} \\
Maravilha & $21 \mathrm{a}^{1}$ & $330 \mathrm{a}$ & $66 \mathrm{a}$ & $89 \mathrm{~b}$ & $237 \mathrm{ab}$ & $318 \mathrm{~b}$ & $37.5 \mathrm{~b}$ \\
Caiapó & $22 \mathrm{a}$ & $301 \mathrm{~b}$ & $65 \mathrm{a}$ & $109 \mathrm{a}$ & $227 \mathrm{ab}$ & $372 \mathrm{a}$ & $45.3 \mathrm{a}$ \\
IAC 202 & $21 \mathrm{a}$ & $308 \mathrm{~b}$ & $66 \mathrm{a}$ & $104 \mathrm{a}$ & $219 \mathrm{~b}$ & $322 \mathrm{~b}$ & $49.3 \mathrm{a}$ \\
BRS Primavera & $22 \mathrm{a}$ & $299 \mathrm{~b}$ & $71 \mathrm{a}$ & $90 \mathrm{~b}$ & $241 \mathrm{a}$ & $350 \mathrm{ab}$ & $31.5 \mathrm{~b}$ \\
\hline ANOVA (F probability) & & & & & & \\
Cultivar (C) & 0.1341 & 0.0646 & 0.4653 & $<0.0001$ & 0.0919 & 0.0072 & 0.0002 \\
K level (L) & 0.0638 & 0.1677 & $<0.0001$ & 0.0032 & $<0.0001$ & $<0.0001$ & 0.7214 \\
C x L & 0.3142 & 0.2206 & 0.1034 & 0.1315 & 0.2175 & 0.2476 & 0.1033 \\
CV(\%) & 12.52 & 11.30 & 15.59 & 8.63 & 11.31 & 10.39 & 16.68 \\
\hline
\end{tabular}

${ }^{1}$ Values followed by the same letter vertically are not significantly different at $\mathrm{P}<0.05$ according to a LSD test. SDM: shoot dry matter; SNC: shoot nutrient content.

The low $\mathrm{Ca}$ and $\mathrm{Zn}$ use efficiency by the modern and intermediate cultivar groups (Maravilha and BRS-Primavera) is related to the higher accumulation of these nutrients and shoot dry matter production (Table 4). Despite the small variations observed, these results showed that the cultivars exhibit similar characteristics regarding the conversion rate of nutrients into dry matter. In addition to genetic factors, the physiological changes caused by environmental conditions during the cultivation period caused changes in the efficiency of nutrient absorption (FAGERIA; MOREIRA, 2011).
The highest $\mathrm{K}$ use efficiency was observed with application of $20 \mathrm{mg} \mathrm{dm}^{-3}$ of $\mathrm{K}$ (Figure 8a). Although higher $\mathrm{K}$ levels increase nutrient content in plant structures (Figure 5a, 5b, 5c, 6a, 6b, and 6c), the effect resulted in lower conversion of nutrients into dry matter. According to Rosolem et al. (1993), the $\mathrm{K}$ availability in the soil negatively affects the uptake of other cations, including $\mathrm{Ca}$ and $\mathrm{Mg}$, which are directly related to the synthesis of plant dry matter (root and shoot). The influence of $\mathrm{K}$ availability on these cationic macronutrients can be observed in the present experiment by the $\mathrm{Ca}$ and $\mathrm{Mg}$ shoot concentration data (Figures $4 \mathrm{~b}$ and $4 \mathrm{c}$ ).
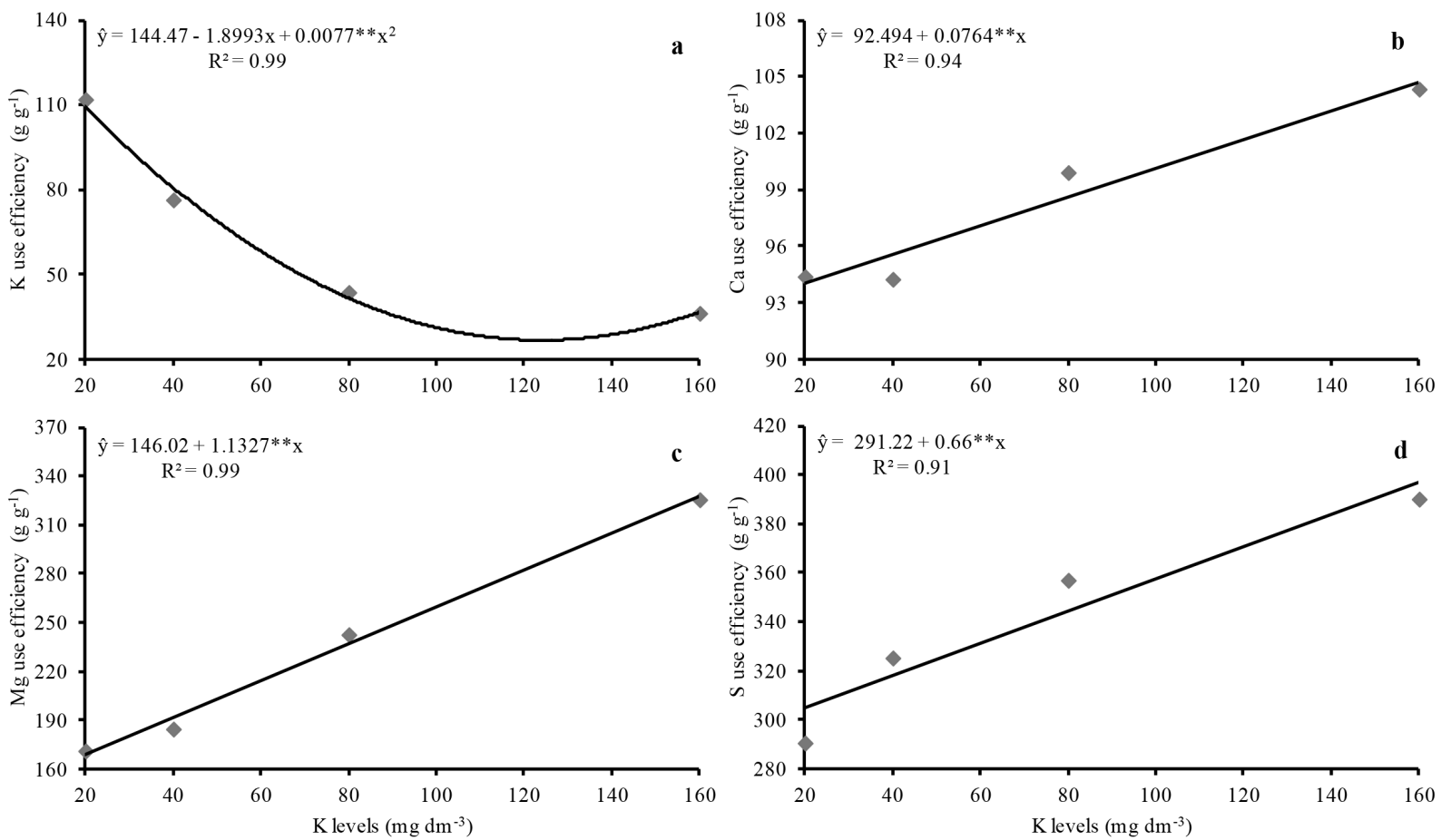

Figure 8. Potassium (a), calcium (b), magnesium (c) and sulfur (d) use efficiency of upland rice as affected by increasing $\mathrm{K}$ levels. ${ }^{* *}$ significantly different at $\mathrm{p} \leq 0.01$.

The $\mathrm{Ca}, \mathrm{Mg}$ and $\mathrm{S}$ use efficiency increased according to the increase of $\mathrm{K}$ fertilization in the soil (Figures $8 \mathrm{~b}, 8 \mathrm{c}$ and $8 \mathrm{~d}$, respectively). These results can be explained by the low total dry matter production. The $\mathrm{Ca}, \mathrm{Mg}$ and $\mathrm{S}$ use efficiency improved as the $\mathrm{K}$ availability increased root and shoot growth. According to Fageria, Baligar and Jones (2011a), the nutrient use efficiency may vary depending on the nutrient balance in the plant, and when an element shows lower availability in the soil, the accumulation of dry matter by the plant is limited, leading to a decline in the use efficiency of 
other nutrients.

\section{CONCLUSIONS}

The application of $\mathrm{K}$ in the soil increases plant biomass, length density and root diameter of upland rice cultivars. The $\mathrm{K}$ shoot concentration is similar for all cultivars evaluated. Increasing $\mathrm{K}$ levels in the soil reduces $\mathrm{Ca}, \mathrm{Mg}$, and $\mathrm{S}$ shoot concentration, but increases use efficiency of these nutrients by upland rice plants.

\section{REFERENCES}

ClOVER, M. W.; MALlARINO, A. P. Corn and soybean tissue potassium content responses to potassium fertilization and relationship with grain yield. Soil Science Society of America Journal, Madison, v. 77, n. 2, p. 630-642, 2013.

COSTA, S. E. V. G. A. et al. Distribuição de potássio e de raízes no solo e crescimento de milho em sistemas de manejo do solo e da adubação em longo prazo. Revista Brasileira de Ciência do Solo, Viçosa, v. 33, n. 5, p. 1291-1301, 2009.

CRUSCIOL, C. A. C. et al. Doses de fósforo e crescimento radicular de cultivares de arroz de terras altas. Bragantia, Campinas, v. 64, n. 4, p. 643-649, 2005.

CRUSCIOL, C. A. C. et al. Macronutrient uptake and removal by upland rice cultivars with different plant architecture. Revista Brasileira de Ciência do Solo, Viçosa, v. 40, 2016.

CRUSCIOL, C. A. C. et al. Upland Rice growth and mineral nutrition as affected by cultivars and sulfur availability. Soil Science Society of America Journal, Madison, v. 77, n. 1, p. 328-335. 2013.

DALIPARTHY, J.; BARKER, A. V.; MONDAL, S. S. Potassium fractions with other nutrients in crops. A review focusing on the tropics. Journal of Plant Nutrition, Philadelphia, v. 17, n. 1, p. 1859-1886, 1994.

FAGERIA, N. K.; BALIGAR, V. C.; JONES, C. A. Growth and mineral nutrition of field crops. 3. ed. Boca Raton: CRC Press, 2011a. 560 p.

FAGERIA, N. K.; BALIGAR, V. C.; LI, Y. C. The role of nutrient efficient plants in improving crop yields in the twenty first century. Journal of plant nutrition, Philadelphia, v. 31, n. 6, p. 1121-1157. 2008.
FAGERIA, N. K.; MOREIRA, A. The role of mineral nutrition on root growth of crop plants. Advances in Agronomy, New York, v. 110, n. 1, p. 251-331, 2011.

FAGERIA, N. K.; MOREIRA, A.; COELHO, A. M. Yield and yield components of upland rice as influenced by nitrogen sources. Journal of plant nutrition, Philadelphia, v. 34 , n. 1, p. 361-370, $2011 b$.

FARINELLI, R. et al. Características agronômicas de arroz de terras altas sob plantio direto e adubação nitrogenada e potássica. Revista Brasileira de Ciência do Solo, Viçosa, v. 28, n. 3, p. 447-454, 2004.

GUIMARÃES, C. M. et al. Sistema radicular do arroz de terras altas sob deficiência hídrica. Pesquisa Agropecuária Tropical, Goiânia, v. 41, n. 1, p. 126134,2011

HALLMARK, W. B.; BARBER, S. A. Root growth and morphology, nutrient uptake, and nutrient status of soybean as affected by soil $\mathrm{K}$ and bulk density. Agronomy Journal, Madison, v. 73, n. 5, p. 779782,1981

HORN, D. et al. Parâmetros cinéticos e morfológicos da absorção de nutrientes em cultivares de milho com variabilidade genética contrastante. Revista Brasileira de Ciência do Solo, Viçosa, v. 30, n. 1, p. 77-85, 2006.

HSIAO, T. C. et al. AquaCrop - The FAO crop model to stimulate yield response to water: III. Parameterization and testing for maize. Agronomy Journal, Madison, v. 101, n. 3, p. 448-459, 2009.

KAMINSKI, J. et al. Depleção de formas de potássio do solo afetada por cultivos sucessivos. Revista Brasileira de Ciência do Solo, Viçosa, v. 31, n. 5, p. 1003-1010, 2007.

LOPES, R. A. et al. Doses, fontes e épocas de aplicação de nitrogênio em arroz de terras altas cultivado em sistema semeadura direta. Revista Caatinga, Mossoró, v. 26, n. 4, p. 79-87, 2013.

MALAVOLTA, E.; VITTI, G. C.; OLIVEIRA, S. A. Avaliação do estado nutricional de plantas: princípios e aplicações. 2. ed. Piracicaba, SP: Potafós, 1997. 309 p.

MEDEIROS, R. D.; SOARES, A. A.; GUIMARÃES, R. M. Compactação do solo e manejo da água. I: efeitos sobre a absorção de N, P, $\mathrm{K}$, massa seca de raízes e parte aérea de plantas de arroz. Ciência e Agrotecnologia, Lavras, v. 29, n. 5, p. $940-947,2005$. 
MORTVEDT, J. J.; KHASAWNEH, F. E. Effects of growth responses on cationic relationships in plants. Soil Science, Baltimore, v. 141, n. 3, p. 200-207, 1986.

OLIVEIRA, R. H.; ROSOLEM, C. A.; TRIGUEIRO, R. M. Importância do fluxo de massa e difusão no suprimento de potássio ao algodoeiro como variável de água e potássio no solo. Revista Brasileira de Ciência do Solo, Viçosa, v. 28, n. 3, p. 439-445, 2004.

ORTEGA, A. E.; MALAVOLTA, E. Los más recientes micronutrientes vegetales. Informaciones Agronómicas de Hispanoamérica, Georgia, v. 7, n. 1, p. 16-25, 2012.

RAIJ, B. VAN et al. Análise química para avaliação da fertilidade de solos tropicais. Campinas, SP: IAC, 2001. 284 p.

ROSOLEM, C. A. et al. Potassium fertilization, root morphology and potassium absorption by soybean. Journal of Plant Nutrition, Philadelphia, v. 16, n. 3, p. 479-492, 1993.

SAINJU, U. M.; SINGH, B. P.; WHITEHEAD, W. F. Tillage, cover crops, and nitrogen fertilization effects on cotton and sorghum root biomass, carbon, and nitrogen. Agronomy Journal, Madison, v. 97, n. 5, p. 1279-1290, 2005.

SANTOS, A. B.; STONE, L. F.; VIEIRA, N. R. A. A cultura do arroz no Brasil. 2. ed. Santo Antônio de Goiás, GO: Embrapa Arroz e Feijão, 2006. 1000 p.

SAS Institute. Procedure guide for personal computers. 5. version. Cary: Analytics, Business Intelligence and Data Management, 1999.

SLATON, N. A. et al. Correlation and calibration of soil potassium availability with rice yield and nutritional status. Soil Science Society of America Journal, Madison, v. 73, n. 4, p. 1192-1201, 2009

TANOI, K. et al. The analysis of magnesium transport system from external solution to xylem in rice root. Soil Science and Plant Nutrition, Oxon, v. 57, n. 1, p. 265-271, 2011.

TENNANT, D. A. Test of a modified line intersect method of estimating root length. Journal of Ecology, Oxford, v. 63, n. 3, p. 995-1001, 1975.

YANG, X. E. et al. Room-induced changes of potassium in the rhizosphere of lowland rice. Communication in Soil Science and Plant Analyses, New York, v. 36, n. 13, p. 1947-1963, 2005.
ZARATIN, C. et al. Efeitos de quatro doses de potássio em seis cultivares de arroz de sequeiro irrigados por aspersão. I. Componentes de produção e produtividade. Científica, Jaboticabal, v. 32, n. 2, p. 115-120, 2004.

ZOBEL, R. W. Sensitivity analysis of computer based diameter measurement from digital images. Crop Science, Madison, v. 43, n. 2, p. 583-591, 2003. 